\title{
Quantitative Method for the Determination of 17-Oxosteroid Fractions by Thin-Layer Chromatography ${ }^{1}$ )
}

\author{
By D. Mrkac-Dević, M. Mišríc and H. Stanković \\ From the Medical Faculty University of Zagreb, Hospital Dr. M. Stojanovic and "Krka" Tovarna Zdravil, \\ Research Development Institute, Novo Mesto, Yugoslavia
}

(Eingegangen am 10. November 1969)

17-oxosteroid fractions were determined quantitatively by thin-layer chromatography. A small glass "extractor" was constructed for the rapid extraction of hormones from a silica plate with minimal losses. This apparatus is genctally applicable for extracting material from thin-layer plates. The hydrolysis and final Zimmermann reaction were performed in the same way as in the procedure for total 17-oxosteroids. Every fraction was identified on the plate by a coloured reaction, extracted, and the Zimmermann reaction was carried out in the tube in the classical way. The method was proved for accuracy and reproducibility.

17-Oxosteroid-Fraktionen wurden durch Dünnschichtchromatographie quantitativ bestimmt. Ein kleines Extraktionsgerät aus Glas für die schnelle Extraktion der Hormone von der Silikagelplatte mit nur geringen Verlusten wurde konstruiert. Dieses Gerät ist generell zur Extraktion von Material aus Dünnschichtplatten geeignet. Hydrolyse und anschließende Zimmermann-Reaktion wurden in gleicher Weise wie zur Bestimmung der Gesamt-17-Oxosteroide durchgeführt. Dic einzelnen Fraktionen wurden durch Farbreaktion auf der Platte identifiziert, die Zimmermann-Reaktion wurde in klassischer Weise im Reagenzglas durchgeführt. Die Methode wurde hinsichtlich Genauigkeit und Reproduzierbarkeit geprüft.

The sources of steroid metabolites differ according to sex and pregnancy; therefore values for total 17-oxosteroids may very often be in a normal range in spite of great disturbances in the metabolism of these hormones. An attempt was therefore made at the beginning of this work to obtain more precise information on the composition of the 17-oxosteroid fractions and to find a method for the rapid and reproducible separation of individual hormones.

Thin-layer chromatography was soon found to be suitable for this purpose with its advantages of simplicity and speed of separation. A good separation of hormones on the plates was achieved (2) and it is possible to separate the following fractions: dehydroepiandrosterone, androsterone, aetiocholanolone, 11-oxoandrosterone, 11- $\beta$-hydroxyandrosterone, 11-oxoaetiocholanolone and 11- $\beta$-hydroxyaetiocholanolone. However, the quantitative determination was much more difficult. The reason for this was the insufficient and uncertain detection of spots (2), a high degree of coloured background and the instability of the colour on the plate (3), or the relatively extended extraction procedure (4).

In this paper, for the separation of the fractions on the chromatographic plate, the technique of DETTER and coworkers (1) was applied while an attempt was made to find a simple and rapid method for the identification and quantitative determination.

\section{Procedure}

Acid hydrolysis and the development of the Zimmermann reaction were performed according to the method of CoRKRR and coworkers for total 17-oxosteroids (5). The method of DeTrER

1) 'This paper was presented at the 7th International Congress of Clinical Chemistry, Geneve; September 1969. and coworkers (1) was applied for the preparation of plates and the chromatographic separation of hormones. Instead of alumina, silicagel $G$ (Stahl) was used. On every plate one or two standard mixtures were run. After the last rechromatography the dry chromatogram was sprayed with $30 \%$ phosphoric acid, dried for $10 \mathrm{~min}$ at $110^{\circ} \mathrm{C}$, sprayed with alcoholic phospho-molibdanic acid and dried again at $110^{\circ} \mathrm{C}$ with the appearance of blue spots for the 17-oxosteroids fractions.

The spots were sucked from the plates with the extractor (Fig. 1). The detailed description of the extractor is given in the discussion. Fractions are extracted twice with $1.5 \mathrm{ml}$ of absolute alcohol and shaken for two minutes. An amount of silicagel from the plate, equivalent to that in the spots, is used for a blank. Alcohol extracts were evaporated. The Zimmermann reaction (5) was applied to the dry extracts.

\section{Results and discussion}

In 15 urine samples the comparison of the values for 17-oxosteroids obtained from chromatographic fractions and by the method of CORKER and coworkers (5), did not show any significant difference (Tab. 1).

Tab. 1

Comparison of values for total 17-oxosteroids by the chromatographic fractionation method and the method of CORKER and cographic fractionation method and the

\begin{tabular}{ccc}
\hline $\begin{array}{c}\text { Total } \\
\text { 17-oxosteroids mg/24 hrs } \\
\text { chromatography }\end{array}$ & $\begin{array}{c}\text { Total 17-oxosteroids mg/24 hrs } \\
\text { CoRKER and coworkers }\end{array}$ \\
\hline 1 & 10.7 & 9.2 \\
2 & 11 & 12.1 \\
3 & 18 & 17 \\
4 & 8.3 & 8.4 \\
5 & 25.3 & 14.5 \\
6 & 14.7 & 9.3 \\
7 & 10.3 & 9.1 \\
8 & 10.4 & 7.2 \\
9 & 7.2 & 18.1 \\
10 & 13.5 & 12.5 \\
11 & 20.1 & 6.8 \\
12 & 11.3 & 6.7 \\
13 & 7.1 & 5.8 \\
14 & 7.7 & 11.5 \\
15 & 6 & \\
$\overline{\mathbf{x}}$ & 12.1 & \\
$\mathrm{t}$ & 0.04 & \\
\hdashline $\mathrm{t}_{\mathrm{t}}>\mathrm{t}$ & & \\
\hline
\end{tabular}




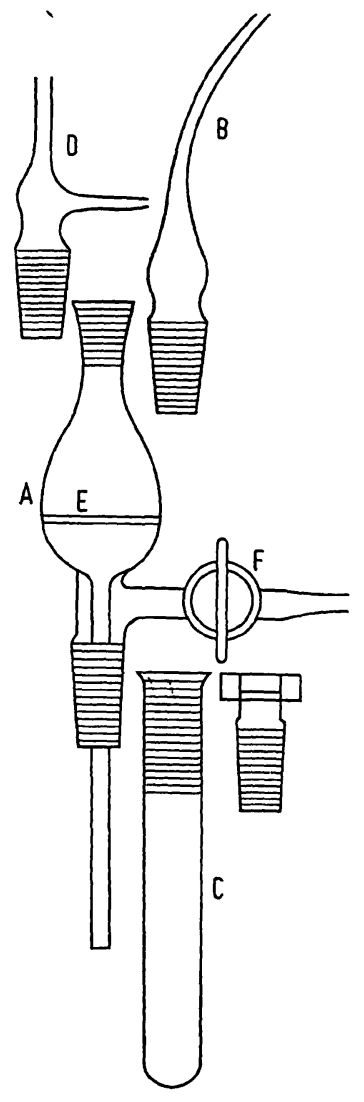

Fig. 1

The extractor
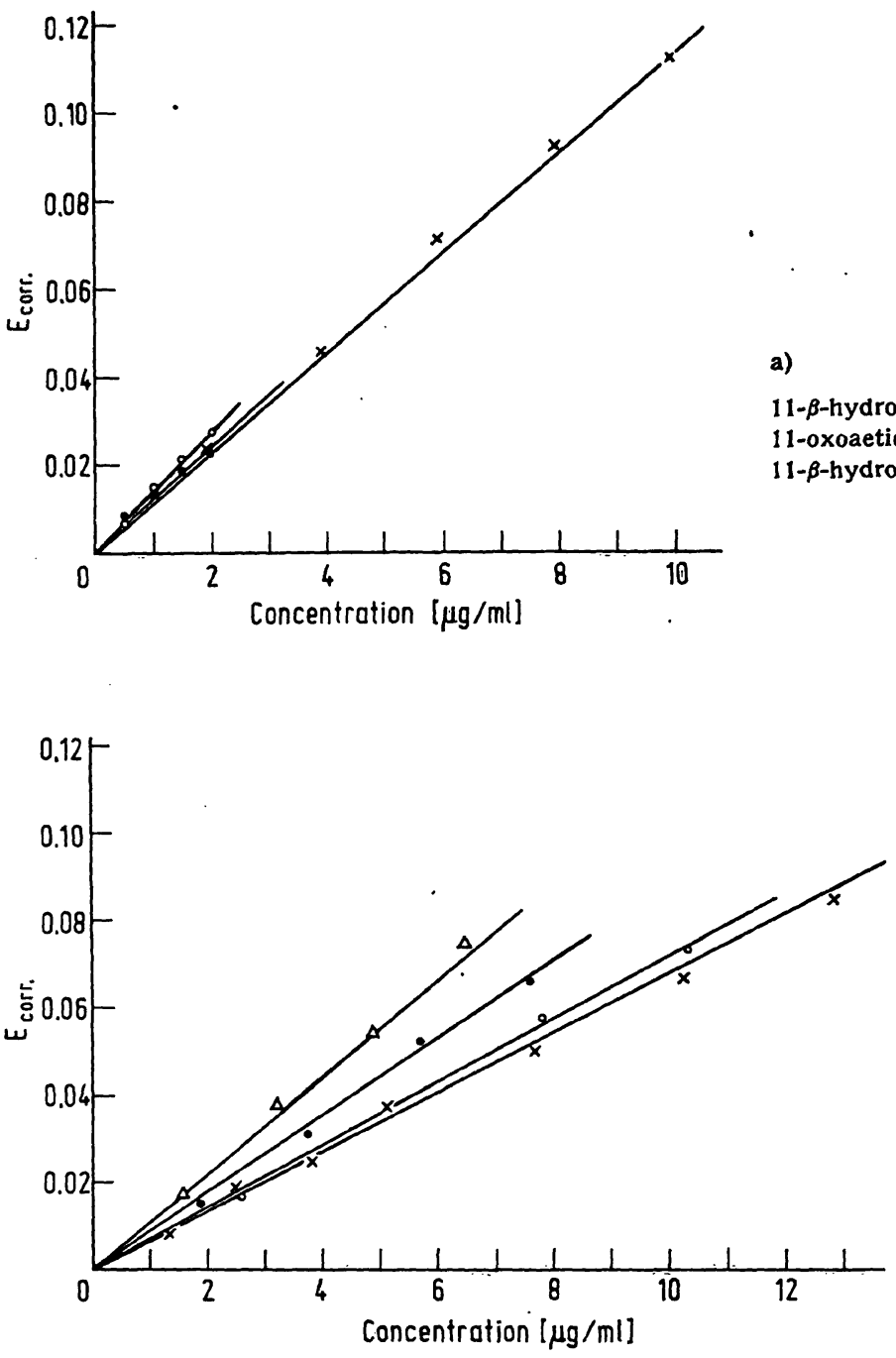

b)

dihydroxyandrosterone - androsterone $0=0$

aetiocholanolone $x-x$

11-oxoandrosterone $\Delta-\Delta$
The advantages of this method are the detection of every spot on the plate and the determination of fractions in a classical way with the Zimmermann reaction. Experiments showed that the presence of phosphoric and phosphomolibdanic acids did not influence the Zimmermann reaction. Pregnandiol and pregnantriol, which are coloured with the same acids, did not influence the final reaction. Furthermore, the glass extractor is very suitable for the extraction from plates and from silicagel and may be used in the other thin-layer chromatography procedures. The extractor (Fig. 1) consists of four parts. For scraping off a coloured spot from the plate, part (A) was combined with part (B). A sinter plate $E \varnothing 3 \mathrm{~cm}$ (G 4) is in part (A). After this, part (A) is connected with part (C), and shaken with the solvent to extract the substance from the silicagel. The substance is poured by the water suction into a glass tube. There, the evaporation and the final reaction take place. The silicagel was removed from the sinter plate in such a way that part (A) on the upper part is connected with part (D) and, using a negative suction with a solvent, silicagel and alumina were removed from the sinter.
The extractor thus washed is prepared for the removal of the next spot from the plate. The extractor is patented (JUS P - 1082/69).

In figure 2 , the linearity of the reaction with the concentration is given for all 7 fractions separated with the proposed procedure.

The standard deviation was calculated for standard samples (tab. 2) and for 13 samples of the unknown (tab. 3).

Table 4 shows the results of analyses of the same sample first alone and then after additions of amounts of standards (Recovery test).

Values for 17-oxosteroids fractions from 11 healthy women aged between 21 and 35 are given (tab. 5).

This method with a precise detection and a rapid and easy way of removing substances from the plate and from silicagel or alumina can be used for the serial and routine determination of 17-oxosteroids.

\section{Acknowledgement}

The authors are indebted to professor Dr. KLYNE, Medical Research Council, Westfield College, Hamstead, London, for the standards collection which enabled the completion of our work. 
Tab. 2

Standard deviation of standard samples in $\mu \mathrm{g}$

\begin{tabular}{|c|c|c|c|c|c|c|c|}
\hline & $\begin{array}{l}\text { Dehydroepi- } \\
\text { androsterone }\end{array}$ & Androsterone & Aetiocholanolone & 11-oxoandrosterone & $\begin{array}{l}11-\beta \text {-hydroxy- } \\
\text { androsterone }\end{array}$ & $\begin{array}{c}\text { 11-oxoaetiochol- } \\
\text { anolone }\end{array}$ & $\begin{array}{l}11-\beta \text {-hydroxy- } \\
\text { aetiocholanolone }\end{array}$ \\
\hline $\begin{array}{c}\text { Concentration } \\
\mathbf{n} \\
\overrightarrow{\mathbf{x}} \\
\mathbf{s d}\end{array}$ & $\begin{array}{l}4.05 \\
5 \\
4.06 \\
0.65\end{array}$ & $\begin{array}{l}5 \\
5 \\
4.98 \\
0.41\end{array}$ & $\begin{array}{l}4 \\
5 \\
4.02 \\
0.81\end{array}$ & $\begin{array}{l}1.3 \\
5 \\
1.36 \\
0.16\end{array}$ & $\begin{array}{l}1.0 \\
5 \\
1.02 \\
0.12\end{array}$ & $\begin{array}{l}1.06 \\
5 \\
1.05 \\
0.17\end{array}$ & $\begin{array}{l}1.06 \\
5 \\
1.08 \\
0.34\end{array}$ \\
\hline
\end{tabular}

Tab. 3

Standard deviation of unknown sample in $\mathrm{mg} / 24$ hours

\begin{tabular}{|c|c|c|c|c|c|c|c|c|}
\hline & $\begin{array}{l}\text { Dehydroepi- } \\
\text { androsterone }\end{array}$ & Androsterone & Aetiocholanolone & 11-oxoandrosterone & $\begin{array}{l}11-\beta \text {-hydroxy- } \\
\text { androsterone }\end{array}$ & $\begin{array}{l}\text { 11-oxoaetiochol- } \\
\text { anolone }\end{array}$ & $\begin{array}{l}11-\beta \text {-hydroxy- } \\
\text { aetiocholanolone }\end{array}$ & Total \\
\hline $\begin{array}{r}1 \\
2 \\
3 \\
4 \\
5 \\
6 \\
7 \\
8 \\
9 \\
10 \\
11 \\
12 \\
13\end{array}$ & $\begin{array}{l}2.14 \\
2.27 \\
2.60 \\
2.2 \\
2.08 \\
2.6 \\
2.6 \\
2.34 \\
2.34 \\
2.30 \\
2.60 \\
2.4 \\
2.08\end{array}$ & $\begin{array}{l}3.3 \\
3.6 \\
3.3 \\
3.3 \\
3.8 \\
4.2 \\
3.05 \\
3.05 \\
3.27 \\
3.70 \\
4.03 \\
3.64 \\
3.7\end{array}$ & $\begin{array}{l}4.6 \\
3.2 \\
4.08 \\
3.9 \\
3.6 \\
3.4 \\
3.37 \\
4.4 \\
4.37 \\
3.05 \\
3.25 \\
4.4 \\
3.9\end{array}$ & $\begin{array}{l}0.00 \\
0.25 \\
0.00 \\
0.00 \\
0.78 \\
0.00 \\
0.00 \\
0.00 \\
0.00 \\
0.00 \\
0.00 \\
0.00 \\
0.00\end{array}$ & $\begin{array}{l}0.00 \\
0.29 \\
0.52 \\
0.00 \\
0.28 \\
0.30 \\
0.00 \\
0.00 \\
0.00 \\
0.13 \\
0.50 \\
0.00 \\
0.09\end{array}$ & $\begin{array}{l}0.00 \\
0.22 \\
0.00 \\
0.53 \\
0.40 \\
0.48 \\
0.52 \\
0.39 \\
0.10 \\
0.29 \\
0.45 \\
0.53 \\
0.07\end{array}$ & $\begin{array}{l}0.00 \\
0.21 \\
0.00 \\
0.00 \\
0.10 \\
0.17 \\
0.35 \\
0.04 \\
0.34 \\
0.34 \\
0.25 \\
0.00 \\
0.51\end{array}$ & $\begin{array}{r}10.04 \\
10.04 \\
10.05 \\
9.97 \\
10.33 \\
11.25 \\
9.89 \\
10.22 \\
10.42 \\
10.81 \\
11.08 \\
10.97 \\
10.35\end{array}$ \\
\hline$\overline{\mathbf{x}}$ & 2.35 & 3.53 & 3.81 & 0.025 & 0.17 & 0.31 & 0.18 & 10.45 \\
\hline sd & 0.19 & 0.35 & 0.53 & 0.07 & 0.19 & 0.2 & 0.17 & 0.44 \\
\hline
\end{tabular}

Tab. 4

The recovery test

\begin{tabular}{|c|c|c|c|c|c|}
\hline Fraction of 17-oxosteroids & $\mathrm{mg} / 24^{\mathrm{h}}$ & $\begin{array}{c}\text { Added } \\
\mathrm{mg} / 24 \mathrm{~h}\end{array}$ & theoretical & $\begin{array}{l}\text { Results } \mathrm{mg} / 2 \mathbf{2}^{\mathrm{h}} \\
\text { experimental }\end{array}$ & Recovery \% \\
\hline Dehydroepiandrosterone & $\begin{array}{l}2.35 \\
2.35\end{array}$ & $\begin{array}{l}9.5 \\
2.4\end{array}$ & $\begin{array}{c}11.85 \\
4.75\end{array}$ & $\begin{array}{l}9.97 \\
4.08\end{array}$ & $\begin{array}{l}84.4 \\
86\end{array}$ \\
\hline Androsterone & $\begin{array}{l}3.7 \\
3.7\end{array}$ & $\stackrel{13}{3.25}$ & $\begin{array}{c}16.7 \\
6.75\end{array}$ & $\begin{array}{r}14.6 \\
5.9\end{array}$ & $\begin{array}{l}87.0 \\
88.6\end{array}$ \\
\hline Aetiocholanolone & $\begin{array}{l}9.8 \\
9.8\end{array}$ & $\begin{array}{c}12.8 \\
3.2\end{array}$ & $\begin{array}{l}22.6 \\
13.1\end{array}$ & $\begin{array}{l}22.2 \\
12.8\end{array}$ & $\begin{array}{l}98 \\
97.6\end{array}$ \\
\hline 11-oxoandrosterone & $\begin{array}{l}1.86 \\
1.86\end{array}$ & $\begin{array}{l}8.05 \\
2.01\end{array}$ & $\begin{array}{l}9.9 \\
3.87\end{array}$ & $\begin{array}{l}9.4 \\
3.58\end{array}$ & $\begin{array}{l}95 \\
92.6\end{array}$ \\
\hline 11-oxoaetiocholanolone & $\begin{array}{l}2.16 \\
2.16\end{array}$ & $\begin{array}{l}9.9 \\
2.47\end{array}$ & $\begin{array}{r}12.02 \\
4.63\end{array}$ & $\begin{array}{c}10.2 \\
4.62\end{array}$ & $\begin{array}{l}85 \\
99\end{array}$ \\
\hline 11- $\beta$-hydroxyaetiocholanolone & 0.43 & 2.87 & 3.3 & 3.27 & 99 \\
\hline
\end{tabular}

Tab. 5

Values for 17-oxosteroids of normal female persons $\mathrm{mg} / 24^{\mathrm{h}}$

\begin{tabular}{|c|c|c|c|c|c|c|c|}
\hline & $\begin{array}{l}\text { Dehydroepi- } \\
\text { androsterone }\end{array}$ & Androsterone & Aetiocholanolone & 11-oxoandrosterone & $\begin{array}{l}\text { 11- } \beta \text {-hydroxy- } \\
\text { androsterone }\end{array}$ & $\begin{array}{l}\text { 11-oxoaetiochol- } \\
\text { anolone }\end{array}$ & $\begin{array}{l}11-\beta \text {-hydroxy- } \\
\text { aetiocholanolone }\end{array}$ \\
\hline $\begin{array}{r}1 \\
2 \\
3 \\
4 \\
4 \\
5 \\
6 \\
7 \\
8 \\
9 \\
10 \\
11\end{array}$ & $\begin{array}{l}5.5 \\
0.39 \\
0.42 \\
1.4 \\
2.3 \\
0.81 \\
2.4 \\
0.47 \\
1.6 \\
1.2 \\
1.1\end{array}$ & $\begin{array}{l}6.3 \\
0.54 \\
4.1 \\
4.1 \\
3.5 \\
2.1 \\
3.7 \\
3.3 \\
2.1 \\
0.55 \\
1.7\end{array}$ & $\begin{array}{l}1.8 \\
4.4 \\
3.3 \\
2.6 \\
3.7 \\
0.28 \\
2.1 \\
3.6 \\
0.28 \\
0.70 \\
1.6\end{array}$ & $\begin{array}{l}0.7 \\
0.54 \\
1.2 \\
1.0 \\
0.06 \\
0.69 \\
0.15 \\
0.63 \\
0,91 \\
1.35 \\
0.31\end{array}$ & $\begin{array}{l}1.1 \\
0.65 \\
2.4 \\
0.16 \\
0.15 \\
1.4 \\
1.0 \\
1.4 \\
0.64 \\
1.4 \\
0.38\end{array}$ & $\begin{array}{l}1.4 \\
0.51 \\
0.74 \\
0.19 \\
0.35 \\
1.7 \\
1.7 \\
0.8 \\
0.95 \\
1.2 \\
0.52\end{array}$ & $\begin{array}{l}1.4 \\
1.16 \\
2.3 \\
0.62 \\
0.23 \\
0.18 \\
2.2 \\
0.98 \\
0.55 \\
1.2 \\
0.24\end{array}$ \\
\hline $\begin{array}{l}\bar{x} \\
\text { sd }\end{array}$ & $\begin{array}{l}1.6 \\
1.5\end{array}$ & $\begin{array}{l}2.9 \\
1.7\end{array}$ & $\begin{array}{l}2.2 \\
1.4\end{array}$ & $\begin{array}{l}0.7 \\
0.4\end{array}$ & 0.97 & $\begin{array}{l}0.9 \\
0.5\end{array}$ & $\begin{array}{l}1.0 \\
0.7\end{array}$ \\
\hline $\bar{x} \pm 2$ sd. & $0-4.6$ & $0-6.3$ & $0-5$ & $0-1.5$ & $0.17-1.7$ & $0-1.9$ & $0-2.4$ \\
\hline
\end{tabular}

\section{Literature}

1. Detter, F., W. Kollmeier und V. KLingmüller, diese Z. 5 , 153 (1967). - 2. Graef, V. und H. Staudinger, diese Z. 5, 314 (1967). - 3. Hamman, B. L. und M. M. Martin, J. Laborat. Clin. Med. S. Louis 71, 1028 (1968). - 4. Sțarka, L., J. SulcovA,
J. Riedlova und O. Adamec, Clin. Chim. Acta Amsterdam 9, 168 (1964). - 5. Corker, C. S., J. K. NorrmbersKr und R. Thow, Biochem. J. 83, 583 (1962).
Doc. Dr. D. Mikac-Devic Zagreb, Jugoslavia Vinogradska cesta 29 